\title{
Problems of Storing University Library Materials
}

By RALPH H. HOPP

\begin{abstract}
' 'HE SUB JECT OF THIS symposium, "Stor1 age Libraries and Storage Problems" is one of inevitable interest to responsible administrators of libraries. Just as with retirement plans and old age pensions, at some time or another most of us will have to consider the subject seriously.
\end{abstract}

The concept of separate storage libraries is not at all new. At least sixty years or more ago the subject was given concrete consideration by President Eliot of Harvard, who at the turn of the century made specific recommendations for the storage of "dead" books. ${ }^{1}$ Like many progressive ideas of that day, such as were generated by Melvil Dewey, President Eliot, and others, nothing much came of them until nearly a half century later.

Storing books in other areas on the campus away from the main library has been practiced, of course, for many years. Typically, however, books were stored in facilities that were anything but ideal and generally were in otherwise unusable rooms in humid basements of other campus buildings. Many of us, I am sure, have experienced the musty smell of rapidly deteriorating paper that greets one upon entering one of these air-locked, damp storage rooms.

The design and use of a separate storage library for any one particular library system has received little attention in the literature until quite recently. The Wilson and Tauber book on university libraries, published in 1956, gives slight

1 Kimball C. Elkins, "President Eliot and the Storage of 'Dead' Books," Harvard Library Bulletin, VIII (1954), 299-312.
Mr. Hopp is Assistant Director, University of Minnesota Library. This paper was presented at the meeting of the ACRL University Libraries Section, Montreal, June 19, 1960.

attention to it. ${ }^{2}$ The first issue of Library Trends, published in 1952, was devoted to "Current Trends in College and University Libraries" and very little if any space was given to the subject of storage.

It was just twenty years ago that the first separate library storage building came into being on any campus in this country. Iowa State University at Ames, in 1940, constructed such a building and, in a sense, pioneered the movement which is now becoming of general concern to many university libraries. ${ }^{3}$ Shortly afterward Harvard, through the New England Deposit Library, also utilized the separate storage facility. ${ }^{4}$

The chief concerns of past discussions on book storage have been primarily in areas of physical dimensions and economics. To enumerate only a few, I could mention discussions of such questions as: How do you determine capacities of given areas by the use of formulas of " $\mathrm{X}$ " volumes per square feet or per cubic feet? What is the optimum height of stacks for efficient storage of books? What is the average proportion of octavos, quartos, and folios that ought to

L. R. Wilson and M. F. Tauber. The University Library, 2nd ed. (New York, Columbia University Press, 1956), pp. 54-55, 469-70, 521-22.

${ }^{3}$ Charles E. Friley and Robert W. Orr, "A Decade of Book Storage at Iowa State College," CRL, XII (1951), 7-10, 19 .

4 Keyes D. Metcalf, "The New England Deposit Library after Thirteen Years," Harvard Library Bulletin, VIII (1954), 313-22. 
be used in figuring book storage capacities? How many and what size should range aisles be? What should be the proper distance between ranges and what effect do these distances have on capacity? What are the relative costs of compact versus standard stacks and how much gain is there in storage capacity when the compacts are used? What are the comparative merits and costs of storage of material as opposed to microreproduction of them? While these are all important questions that need answers, there are still more basic considerations.

Fundamental to any decision to build a storage unit is this question: Is it cheaper to store materials than it is to weed? It is a curious thing in the library profession that almost anyone can make the decision to add a volume to the library, but to weed one from the collection often requires endless consultation and the process generally becomes so costly that weeding is seldom done to the extent that it perhaps otherwise would be.

Probably the most frequently given reason for building a storage library is simply that it provides a means for extending the life of the main library building. An adequate plan that results in more than just a postponement of the day when a new main library will be built must be based not only on a study of weeding that can be done or the selection of the materials that can be moved to storage, but also upon an analysis of the growth of the collection, as was done by Mr. Metcalf. ${ }^{5}$ A study of prospective space needs during coming years may show that storing from the present collection is not enough but must also include storing a part of new acquisitions. This, of course, has implications for such questions as cooperative acquisitions programs, or brings to the fore that ubiquitous but never solved problem, the acquisitions policy.

5 Ibid.
The development of any library is dependent upon the wisdom of the acquisitions program. If we admit that we have many books that can logically go to storage does this mean that we have selected badly? Or do we only put older materials in storage, maybe hedging against the future and the possibility of need for these materials? The trend toward increased use of storage libraries is undoubtedly a symptom of a much more basic problem. Aren't we approaching the time when we have to start actively considering the necessity for specialization among institutions in the development of collections? Whether desirable or not, few institutions can afford the luxury of having every book or periodical it might conceivably need within easy paging accessibility. After all, books that can be borrowed from another institution, whether another university or an organization specializing in cooperative acquisitions and storage, differ in availability only in the matter of degree from books placed in a separate storage building on our own campus. As Mr. Metcalf has pointed out, the New England Deposit Library has demonstrated that the inconvenience entailed in storing library books at a distance from the main library is not an unbearable burden on scholars. In other words, are we deferring decisions that perhaps ought to be made soon rather than wait until library storage buildings become standard items in our institutions' budgetary requests?

If there are those who have been thinking casually of the time when they will be building a storage library, they will want to consider carefully the many factors involved in such a move. At the University of Minnesota we have set up a pilot-plant operation, taking one level of our central stacks as a sample storage unit. This was done in anticipation of our move to a storage building soon to be constructed in an off-campus location about one mile from our main library. Some of the problems that have been 
raised in this small-scale operation are more easily handled through this experimental unit than if we were faced with the full-sized storage library.

Before a book is shelved in a new storage unit a decision has to be made as to whether storing by classification number should be adhered to in the shelving. Or isn't classification important in a little used collection? The other alternatives to shelving by classification are: shelving in fixed and compact order arranged by size and in order of receipt; or grouping the material by the unit from which it came, so that, for example, all chemistry library materials will be together as will those that came from other departmental libraries or other library division; or a combination of these methods.

It seems evident that the era of storage libraries is fast approaching, if indeed it has not already arrived. Recognizing that research should precede and determine practice, the Council on Library $\mathrm{Re}$ sources, Inc., recently made two grants for studies in this field. The University of Chicago Library, the recipient of one such grant, is presently working on a project which has as one of its objectives the determination of patterns of use of library materials. ${ }^{6}$ From these it is hoped that standards of selection can be arrived at upon which to base university library book-storage programs. The study will consist of taking a sampling of a given library's book stock in certain subject fields and establishing the amount of circulation selected books have undergone since their acquisition. The books in these various subjects will then be

' Council on Library Resources, Inc. Third Annual Report, for the Period Ending June 30, 1959, p. 33. (Also see CLR's news release, "Recent Developments," No. 17, April 26, 1959.) characterized by such factors as date of publication, language of text, date of acquisition, and others, to determine the bearing of these factors upon book circulation. Several university library collections will be used in the research project.

The Yale University Library, also through a grant from the Council on Library Resources, Inc., is studying the problem of selection of materials for storage. $^{7}$

We are, of course, gradually accumulating experience upon which we can draw as we consider some of the problems faced in setting up storage libraries. As of now, however, one could fairly safely say that there are few experts in this field. I have indicated that Iowa State University has had a storage library for nearly twenty years. Their experience, I believe, has shown that the storage unit has become an important and indispensable part of their library system. The University of Michigan also has a separate building devoted primarily to the storage of selective collections. The Harvard experience with the New England Deposit Library is a matter of published information and falls between the singleunit storage building for one library and the joint cooperative storage plan of the Midwest Inter-Library Center participated in by a group of libraries.

Because of the paucity of published information on storage libraries, reports of the practical considerations, as well as the experimental findings, of day-to-day storage library operations are of continuing interest to a wider and wider audience of university librarians.

\footnotetext{
7 John Ottemiller, F. Bernice Field, and Lee Ash, "The Selective Book Retirement Program at Yale," The Yale University Library Gazette, XXXIV (1959), 64-72. (Also see CLR's news release, "Recent Developments," No. 16, March 18, 1959.)
}

\section{Anniversary Issue}

$C R L$ readers will be interested in the July 1961 issue of Bulletin of the Medical Library Association, which is the anniversary issue on the National Library of Medicine. Special attention might be called to the "Memoirs of Robert Fletcher" by Dr. Estelle Brodman and "Physicians to the Presidents, and Their Patients: A Bibliography" by Charles A. Roos. 